\title{
Detection of Progeny Immune Responses after Intravenous Administration of DNA Vaccine to Pregnant Mice
}

\author{
Ke-Qin Xin ${ }^{1}$, Shin Sasaki ${ }^{2}$, Yoshitsugu Kojima ${ }^{1}$, Nao Jounai ${ }^{1}$, Yasuko Kumamoto ${ }^{1}$, Kumiko \\ Hashimoto ${ }^{1}$, Kaori Shinoda ${ }^{1}$, Kenji Hamajima ${ }^{1}$, and Kenji Okuda ${ }^{1}$. \\ ${ }^{1}$ Department of Bacteriology, Yokohama City University School of Medicine, Yokohama 236-0004, Japan. \\ ${ }^{2}$ Department of Bioregulation, Leprosy Research Center, National Institute of Infectious Diseases, Tokyo 189-0002, Japan. \\ *To whom correspondence should be addressed: Email: kokuda@med.yokohama-cu.ac.jp
}

Submitted: March 5, 2002; Revised: March 24, 2002; Accepted: April 8, 2002; Published: April 23, 2002

\begin{abstract}
A number of factors influence the development of tolerance, including the nature, concentration and mode of antigen presentation to the immune system, as well as the age of the host. The studies were conducted to determine whether immunizing pregnant mice with liposome-encapsulated DNA vaccines had an effect on the immune status of their offspring. Two different plasmids (encoding antigens from HIV-1 and influenza virus) were administered intravenously to pregnant mice. At 9.5 days post conception with cationic liposomes, injected plasmid was present in the tissues of the fetus, consistent with trans-placental transfer. When the offspring of vaccinated dams were immunized with DNA vaccine, they mounted stronger antigen-specific immune responses than controls and were protected against challenge by homologous influenza virus after vaccination. Moreover, such immune responses were strong in the offspring of mothers injected with DNA plasmid 9.5 days after coitus. These results suggest that DNA vaccinated mothers confer the antigen-specific immunity to their progeny. Here we describe the methods in detail as they relate to our previously published work.
\end{abstract}

\section{INTRODUCTION}

Most vaccines intended for human use are administered to infants and children. Due to the immaturity of their immune system, newborns exposed to foreign antigens are at risk of developing tolerance rather than immunity (2-7). For example, if antigen is administered shortly after birth, forbidden clones can emerge and induce such tolerance (2-7). A number of factors influence the development of tolerance, including the nature, concentration and mode of antigen presentation to the immune system, as well as the age of the host $(8,9)$. Over the past decade, there has been considerable interest in the use of DNA vaccines to prevent infection by pathogenic viruses, bacteria and parasites, with phase I clinical trials being initiated against malaria, HIV-1 and hepatitis B virus.
In the present study, we confirmed that plasmid DNA administered to pregnant mice could reach the fetus through the placenta. This was true both of DNA vaccines encoding the env gene of HIV-1 as well as those encoding the influenza virus matrix (M) and nucleoprotein (NP) genes. Analysis of the immune response of offspring whose mothers were immunized with the influenza DNA vaccine indicate that these progenies had enhanced level of protection against the same virus infection.

\section{MATERIALS AND METHODS}

\section{Animals}

We used 6-10-week old BALB/c female mice purchased from Japan SLC, Inc. (Shizuoka, Japan). All mice were allowed free access to sterile food and water.

\section{Viral protein expression plasmids and antibodies}

A pME18S-M expression plasmid was constructed with the pME18S expression vector into which $M$ region cDNA from influenza virus strain $\mathrm{A} / \mathrm{PR} / 8 / 34$ (H1N1) had been inserted (13). pME18S empty vector was used as a control plasmid for $\mathrm{A} / \mathrm{PR} / 8 / 34$ challenge. The expression of the proteins was confirmed by Western blot analysis (10). pCMV160IIIB encoding the $e n v$ gene of HIV-1 strain IIIB has been described in detail in our previous report (11). DNA vaccines of NP (A/pCMV-V1NP) and HA (V1J-HA (PR8)) genes of the A/PR/8/34 strain (14-16) were the kind gifts from Drs. J. J. Donelly and D. Montgomery, Merck Research Lab., West Point, PA. To confirm that plasmid DNA was transferred through the placenta, a lac $\mathrm{Z}$ expression plasmid containing a chicken $\beta$-actin promoter was also used.

(C) 2002 Biological Procedures Online. All rights reserved. Paper-based copying and internal distribution permitted for educational or non-profit purposes. Printing for personal use permitted. Electronic copying, storage or redistribution prohibited. 


\section{Virus Preparation (Protocol I)}

Mouse-adapted influenza A/PR/8/34 (H1N1) viruses were used in this study. Maudin-Darby canine kidney (MDCK) cells were cultured with Eagle's minimum essential medium (MEM, Nissui Corp. Tokyo, Japan) containing $10 \%$ FCS at $5 \% \mathrm{CO}_{2}$, $37^{\circ} \mathrm{C}$. Viruses were harvested from infected MDCK cells and titrated according to the plaque formation method.

\section{DNA immunization (Protocol II)}

Mothers were injected intravenously (i.v.) with DNA vaccine before or after coitus. Preparations containing various doses of the DNA vaccine were encapsulated into liposomes (12).

Briefly, a $\quad 1: 1 \quad$ volume of $\quad 6.01 \quad \mathrm{mg} / \mathrm{ml} \quad 3 \beta\left[\mathrm{N}-\left(\mathrm{N}^{\prime} \mathrm{N}\right.\right.$ 'dimethylaminoethane) carbamoyl] cholesterol (DC-Chol) and $5.99 \mathrm{mg} / \mathrm{ml}$ dioleoylphosphatidylethanolamine (DOPE) in chloroform was mixed with an evaporator set at $40^{\circ} \mathrm{C}$ for $1 \mathrm{hr}$. Five volumes of $20 \mathrm{mM}$ HEPES buffer ( $\mathrm{pH}$ 7.8) was added into the mixture, mixed and kept at $4^{\circ} \mathrm{C}$ overnight to completely dissolve the pellet. Then, the resultant solution was sonicated with a Sonifier 250 (Branson, Danbury, CT) set at output control 2-3; duty cycle 30, for $5 \mathrm{~min}$. The cationic liposomes were stocked at $4^{\circ} \mathrm{C}$ and used within 2-3 months. Prior to administration, an appropriate amount of DNA in phosphate-buffered saline (PBS), pH 7.2, was mixed with the liposome solution at a volume ratio of 1:1. The pregnant mice were i.v. administered the DNA vaccine or empty vector on various days after post conception (p.c.) to assess immunogenicity. Six weeks after birth, their offspring were injected intramuscularly (i.m.) in gastrocnemius muscles with $20-50 \mu \mathrm{g}$ of the same expression plasmid or the empty vector. For the influenza virus challenge experiment $50 \mu \mathrm{g}$ each of plasmids expressing influenza $\mathrm{M}$ and $\mathrm{NP}$ protein was administered into pregnant mice by i.v. route. The same amount of DNA plasmids was administered to offspring by i.m. route.

\section{X-gal staining}

Mouse fetus was cut in two and washed with PBS once followed by incubation at $37^{\circ} \mathrm{C}$ for 30 min with X-gal staining buffer $\left(5 \mathrm{mM} \mathrm{K}_{4} \mathrm{Fe}(\mathrm{CN})_{6} \cdot 3 \mathrm{H}_{2} \mathrm{O}, 5 \mathrm{mM} \mathrm{K} \mathrm{K}_{3} \mathrm{Fe}(\mathrm{CN})_{6}, 20 \mathrm{mM}\right.$ $\mathrm{MgCl}_{2}, 1 \mathrm{mg} / \mathrm{ml} \mathrm{X-gal)}$.

\section{FISH analysis (Protocol III)}

FISH analysis was performed essentially by the method of ElNaggar et al. (17). A 564-bp HIV env region fragment (nt 1569-2133) was amplified from pCMV160IIIB plasmid (10) using primers (5-ATGTGTAACACCTCAGTCATTAC and TTATCTTTTTTCTCTCTGCACCAC-3). The PCR product was purified from $1.5 \%$ agarose gel using QIAquick gel extraction kit (Qiagen) and was labeled with digoxigenin-11dUTP by nick translation. The labeled product (300-560 bp
DNA) was confirmed on $2 \%$ agarose gel and used for a hybridization probe. The tissue samples were taken from mice to which $50 \mu \mathrm{g}$ of HIV plasmid pCMV160IIIB (11) or influenza plasmid V1J-HA(PR8) (14) with liposomes were administered and sliced to prepare histological examination. The samples were denatured and hybridized with digoxigeninlabeled probes using a previously described method (17). After hybridization, the slides were washed and stained with an antidigoxigenin rhodamine (a red fluorochrome: Boehringer Mannheim, Germany). The slides were counterstained with 4,6-diamino-2-phenylindole dihydrochloride (DAPI). Images were made with a Nikon SA fluorescence microscope (Nikon Corp., Tokyo, Japan) and a Charge Coupled Device (CCD) camera interfaced with a Cyto Vision (Applied Imaging, Sunderland, UK).

\section{Cytokine ELIspot assay (Protocol IV)}

The cytokine ELIspot assay was performed with minor modifications, as previously described $(18,19)$. Briefly, 96-well microplates (MAIPS4510, Millipore, Bedford, MA) were coated with anti-mouse IFN- $\gamma$ rat mAb (PharMingen), and after adding cells isolated from the spleen 7 days after immunization, plates were incubated in a $5 \% \mathrm{CO}_{2}$ atmosphere at $37^{\circ} \mathrm{C}$ with or without $10 \mu \mathrm{g} / \mathrm{ml}$ of V3 peptide. After a $24-$ hour culture, plates were washed and incubated again for 2 hours with biotinylated anti-mouse IFN- $\gamma \mathrm{mAb}$ (PharMingen). Then, after staining with alkaline phosphatase, the spots in each well were counted using a computer assisted video image analysis system (Zeiss Co., Germany). By applying the proper dilution factor the total number of cytokine-secreting cells was calculated.

\section{Virus challenge}

Under light diethyl ether anesthesia, the offspring were simultaneously infected with virus at day 10 after immunization with the same plasmid DNA as that administered to their mothers. Five lethal doses $\left(\mathrm{LD}_{50}\right)$ of influenza $\mathrm{A} / \mathrm{PR} / 8 / 34$ (H1N1) in $30 \mu \mathrm{l}$ of PBS were administered by the intratracheal route using a 24-gauge stainless steel animal feeding tube (Popper \& Sons, New York, NY). The mortality rate was determined after 20 days.

\section{Statistical analysis}

Statistical analysis for comparison of two groups was conducted using an unpaired $t$-test or one-way factorial analysis of variance (ANOVA) for distribution parameters. Significance was defined as $\mathrm{p}<0.05$ in both analyses. 

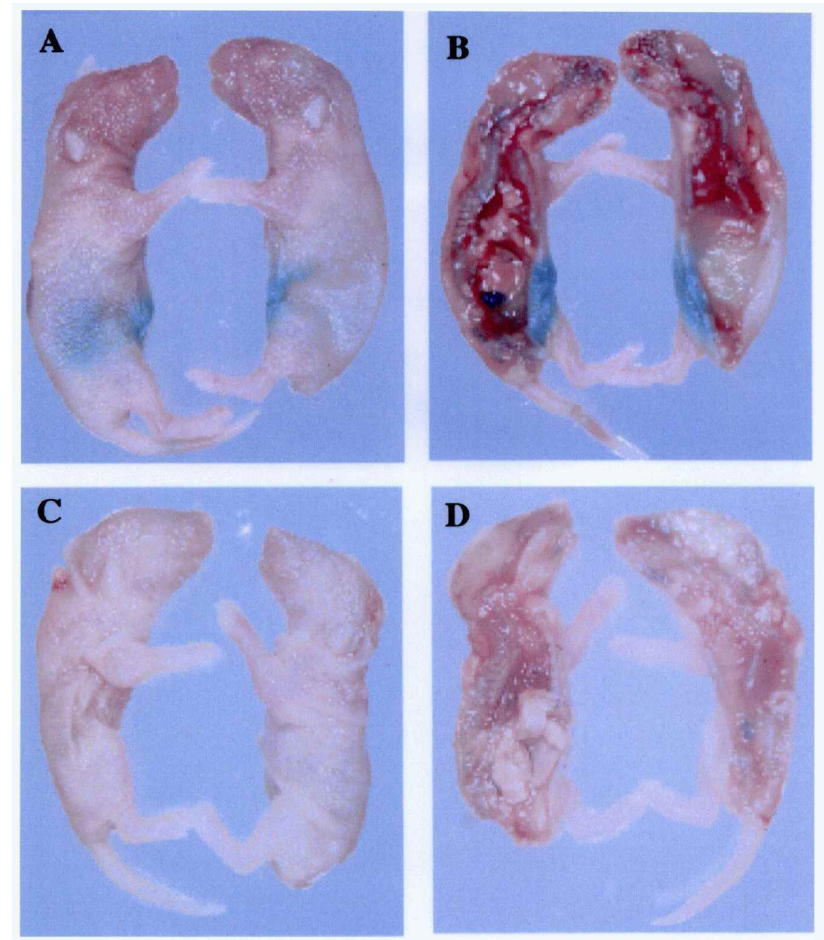

Fig. 1: Gene expression of lac Z in mouse fetus. A and B, Stained tissue of a fetus cut in two, whose mother received $30 \mu \mathrm{g}$ of lacZ plasmid with liposomes at day 9.5 postcoitus (p.c.); C and D, stained tissue of a fetus whose mother received $30 \mu \mathrm{g}$ of empty plasmid with liposomes at day 9.5 p.c.

\section{RESULTS}

\section{Gene transfer into fetuses}

Initial studies examined whether DNA plasmids could be transmitted through the placenta of pregnant mice. To evaluate plasmid uptake and expression in fetal tissue, a plasmid expressing the lac $Z$ gene was utilized. To increase the uptake
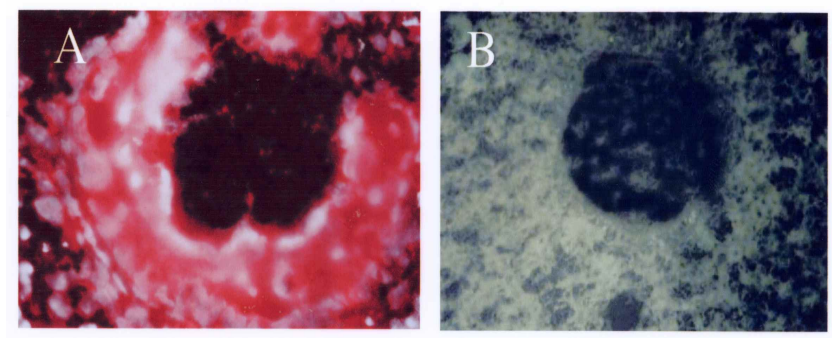

Fig. 2: FISH analysis. Vertebra of a fetus whose mother received HIV plasmid pCMV160IIIB (A) or influenza plasmid V1J-HA (PR8) (B) with liposomes at day 9.5 p.c. These samples were reacted with HIV env region fragment labeled with digoxigenin-11-dUTP, followed by staining with an antidigoxigenin rhodamine. Red fluorochrome indicates the presence of HIV-IIIB DNA. of this plasmid, it was liposome-encapsulated prior to i.v. delivery (8). Tissues from newborn mice from mothers injected with the $l a c Z$ plasmid and liposomes 9.5 days p.c. showed strong expression of that gene (Fig. 1). Of particular interest was the intense staining in the umbilical region of the fetuses. Examination by the FISH method confirmed that abundant plasmid DNA had been transmitted to the fetuses (Fig. 2). We found abundant plasmid DNA in spleen, liver, lung, and other tissues (data not shown).

ELIspot analysis using spleen cells from immunized offspring of vaccinated mothers was performed (Table 1). When stimulated in vitro with vaccine-encoded antigen, a significant increase in the number of spleen cells secreting IFN- $\gamma$ was observed.

Table 1: ELIspot analysis of IFN- $\gamma$ producing spleen cells from DNA-vaccinated mice whose mothers had been injected with the same vaccine during pregnancy.

\begin{tabular}{|c|c|c|}
\hline \multicolumn{2}{|c|}{ Immunogen administered to } & IFN- $\gamma$ producing cells \\
\hline Pregnant mothers & Progenies & $\left(\mathrm{Spot} / 10^{6}\right.$ spleen cells $)$ \\
\hline 1. pCMV160IIIB & $\dagger^{\cdots}$ 160IIIB & $42.6 \pm 9.6^{*}$ \\
\hline 2. pCMV160IIIB & mmune & $20.6 \pm 6.7$ \\
\hline 3. Empty vector & $160 \mathrm{IIIB}$ & $28.2 \pm 3.5^{*}$ \\
\hline 4. Empty vector & Empty vector & $16.7 \pm 6.3$ \\
\hline 5. Non-immune & Non-immune & $13.9 \pm 5.9$ \\
\hline $\begin{array}{l}\text { At day } 9.5 \text { p.c., pregnant } \\
\text { pCMV160IIIB or empty } \\
\text { offspring were immunize } \\
\text { vector as received by their } \\
\text { and cocultured with V3 pe } \\
\text { mice. *Indicates significar } \\
\text { (control). 'Means a signif } \\
\text { Data from two other experi }\end{array}$ & $\begin{array}{l}\text { BALB/c mice wer } \\
\text { ector with liposom } \\
\text { i.m. with } 50 \mu \mathrm{g} \text { o } \\
\text { mothers. After } 7 \text { da } \\
\text { tide for } 24 \text { hours. D } \\
\text { t difference }(\mathrm{p}<0.05) \\
\text { icant difference betw } \\
\text { ments showed simila }\end{array}$ & $\begin{array}{l}\text { i.v. injected with } 50 \mu \mathrm{g} \text { of } \\
\text { Six weeks after birth the } \\
\text { the same plasmid or empty } \\
\text { s, spleen cells were collected } \\
\text { a represent means } \pm \text { SE of } 6-8 \\
\text { ompared to the empty vector } \\
\text { en the two indicated values. } \\
\text { results. }\end{array}$ \\
\hline
\end{tabular}

\section{Challenge test with influenza virus}

To examine the immunoprotective effect of maternal vaccination with a DNA vaccine against influenza virus, offspring were immunized with $50 \mu \mathrm{g}$ of the same vaccine at 6 weeks of age. Seven days later they were challenged with influenza virus $\mathrm{A} / \mathrm{PR} / 8 / 34$. More than $70 \%$ of the offspring of vaccinated mothers survived (Fig. 3), whereas only $20 \%$ of the offspring of non-vaccinated mothers survived. All of the nonimmunized offspring whose mothers received liposomes alone or were not immunized had died.

The timing of maternal DNA vaccination on the capacity of offspring to develop protective immunity was then examined. Whereas $<20 \%$ of normal vaccinated mice (and offspring of mothers vaccinated 20 days prior to mating) survived the 


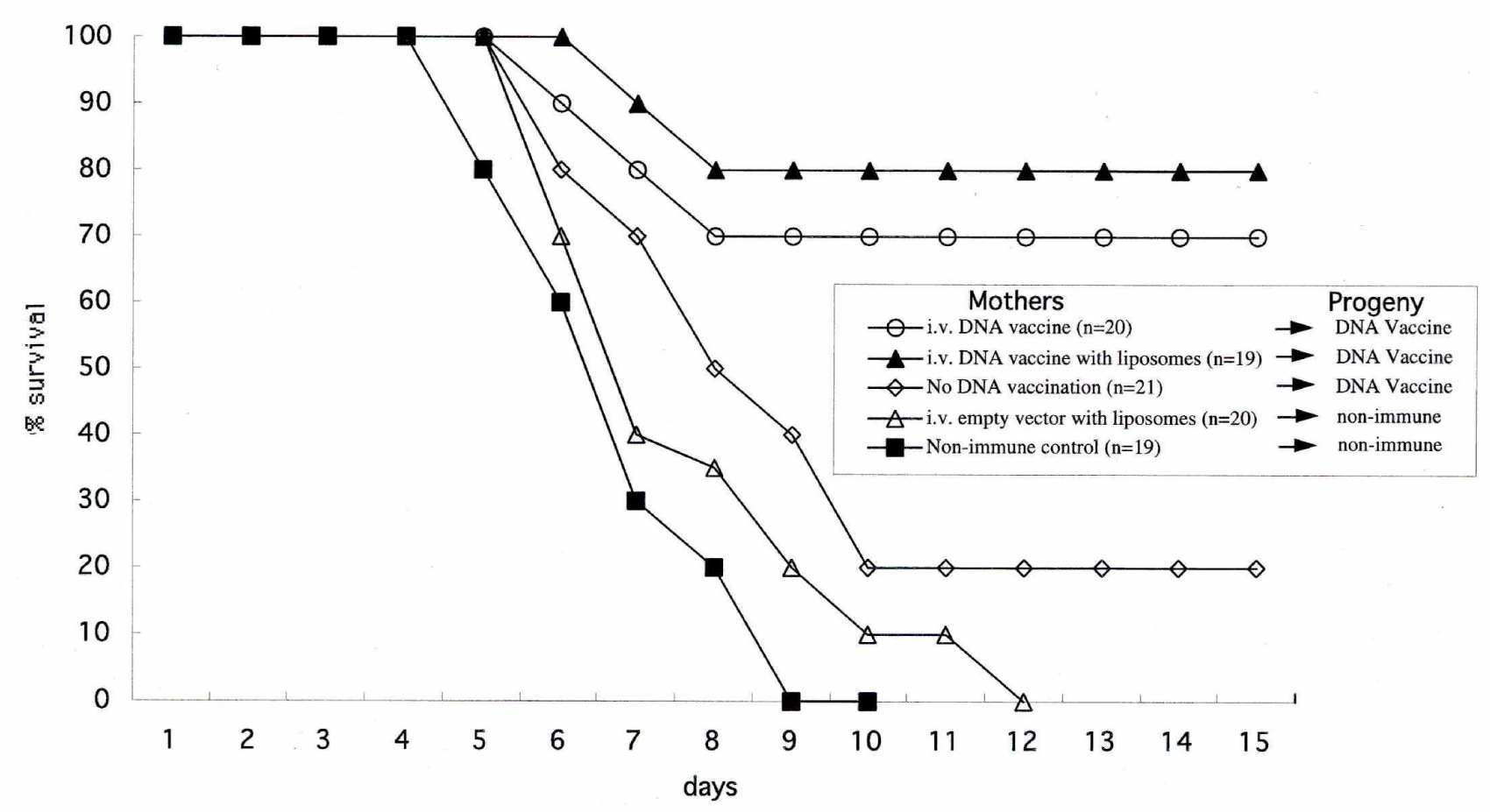

Fig. 3: Protection of offspring against a lethal $\mathbf{A} / \mathbf{P R / 8 / 3 4}$ influenza virus challenge. Day 9.5 p.c. pregnant BALB/c mice were i.v. injected with $50 \mu \mathrm{g}$ each of pME18S-M and pCMV-V1NP with or without liposomes. Six weeks after birth, their offspring were immunized i.m. with a total of $50 \mu \mathrm{g}$ of the same plasmid DNA with liposomes. In one group, offspring of mothers that had received DNA vaccine with liposomes were not administered vaccine. In another group, the mother and progenies received only empty vector. Non-immunized normal mice were used as the other control. After 7 days, all mice were challenged with 5xLD50 of A/PR/8/34 virus. The percentage of survival of these mice was studied for another 15 days. $n$, number of mice.

challenge, $>50 \%$ of the offspring of immunized mothers survived (Table 2).

These findings indicate that immunization of mothers with a DNA vaccine against the influenza virus improves the ability of their offspring to develop protective immunity against viral challenge post vaccination.

\section{DISCUSSION}

Two independent techniques were used to establish that plasmid DNA administered to pregnant mice could reach the fetus. One is the administration of a $\beta$-gal encoding plasmid which allowed for the direct identification of protein expression in neonates. Intense staining of the placenta was consistent with transplacental migration of the plasmid. The other technique is the FISH method which was used to directly detect plasmid DNA in fetal tissue (Fig. 2). Our results confirm and extend the previous finding (10) that in mice a $\beta$ gal plasmid can be transmitted through the placenta to the fetus. Of particular importance, we established that such trans- placental transfer influences the recipients' subsequent capacity to mount an immune response against the plasmidencoded antigen. This was manifested by improved cellular immunity (Table 1) and higher levels of pathogen-specific protection (Fig. 3 and Table 2).

These studies were also performed to test the hypothesis that the administration of a DNA vaccine during pregnancy may induce antigen-specific tolerance in the offspring, as suggested by the clonal selection theory of Burnet $(3,4,20)$. Although pregnant mice were immunized with various doses of several different DNA vaccines, we found that immunity but not tolerance was elicited in the fetus (Fig. 3 and Tables $1 \& 2$ ). Using this technique, we did not observe antigen-specific immune tolerance in progeny as reported by Mor et al. (21). This could reflect our use of a different plasmid (Mor et al. detected tolerance following neonatal immunization with a plasmid encoding the circumsporozoite protein of malaria), or the very limited amount of plasmid actually transferred transplacentally. Indeed, Ichino et al. demonstrated that neonatal tolerance was dose-dependent, and could be reliably induced 
only when $>10 \mu \mathrm{g}$ of plasmid was injected into newborn mice (8). This is consistent with other reports showing that low dose antigen can induce immune responsiveness, while high dose immunization can induce tolerance in young recipients $(9,22,23)$. This might be in support of Burnet's theory that high levels of neonatal antigen can trigger clonal deletion $(4,8)$.

Table 2: The importance of timing the DNA immunization of pregnant mothers against $\mathrm{A} / \mathrm{PR} / 8 / 34$ virus challenge.

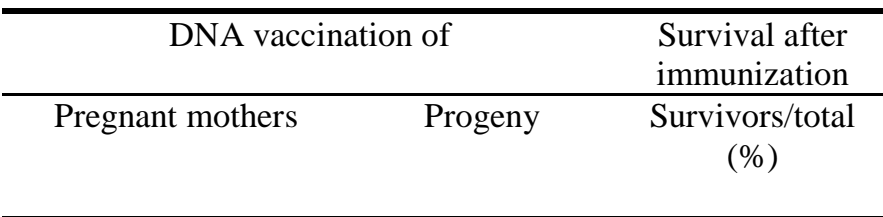

\section{DNA vaccination}

20 days before coitus

DNA vaccination

$3 / 19(15.8)$

day 5.5 p.c.

DNA vaccination

$5 / 20(25.0)$

day 9.5 p.c.

DNA vaccination

$11 / 21(52.3)^{*}$

day 14.5 p.c.

DNA vaccination

$12 / 19(63.2)^{*}$

day 9.5 p.c.

no vaccination

$3 / 18(16.7)^{*}$

\section{Empty vector}

day 9.5 p.c. $\quad$ DNA vaccination $\quad 2 / 22(9.1)$

\section{Non-immune control Non-immune $\quad 1 / 19$ (5.3)}

Pregnant BALB/c mice were i.v. injected with $25 \mu \mathrm{g}$ each of $\mathrm{A} / \mathrm{pCMV}$ V1NP ${ }^{+}$pME18S-M and liposomes on day $5.5,9.5$ or 14.5 p.c. Six weeks after birth, all offspring were immunized i.m. with $50 \mu \mathrm{g}$ of the same plasmid DNA as received by their mothers. After 7 days, these mice were challenged with $5 \times \mathrm{XD}_{50}$ of $\mathrm{A} / \mathrm{PR} / 8 / 34$ and the per cent survival was determined after another 20 days. Data represent means \pm SE of 19-22 mice. *Indicates statistically significant difference $(\mathrm{p}<0.05)$ between non-immune control group. Data from another separate experiment showed similar results.

When offspring of vaccinated mothers were immunized at 6 weeks of age with the same DNA vaccine, they displayed significant anamnestic responses. Re-immunization was required, however, since trans-placental transport of plasmid alone did not trigger strong immune responses in the newborn, or provide adequate protection from infection (Fig. 3 and Table 2 ). On the other hand, re-exposure of these mice to vaccine at 6 weeks of age elicited a strong, protective immune response characterized by antigen-specific antibody, CTL and cytokine responses. The administration of DNA vaccine into amniotic fluid induced a high level of protective immunity (24). In the present study, when DNA vaccine was given to mothers, Agspecific acquired immunity was induced in their offspring. Therefore, this method may be effective in the prevention of pertussis, hepatitis type $\mathrm{B}$ and $\mathrm{C}$, mumps, rubella and various other infections occurring in infants as well as animals.

\section{ACKNOWLEDGEMENTS}

This study was supported by a grant-in-aid from the Ministry of Education, Sciences, Sports, and Culture of Japan and by the Japan Health Sciences Foundation (K-1027, SA24713).

\section{REFERENCES}

1. Okuda K, Xin K-Q, Haruki A, Kawamoto S, Kojima Y, Hirahara F, Okada H, Klinman D, Hamajima K. Transplacental genetic immunization after intravenous delivery of plasmid DNA to pregnant mice. J Immunol 2001;167:5478-5484.

2. Spear PG, Edelman GM. Maturation of the humoral immune response in mice. J Exp Med 1974:139:249-263.

3. Billingham RE, Silver WK. Studies on tolerance of the Y chromosome antigen in mice. J Immunol 1960;107:179202.

4. Burnet FM. The colony selection theory of acquired immunity: Cambridge University Press: Cambridge, England; 1959.

5. Dorsch S, Roser B. T cells mediate transplantation tolerance. Nature 1975;258:233-235.

6. Gammon G, Dunn K, Shastri N, Oki A, Wilbur S, Sercarz EE. Neonatal T-cell tolerance to minimal immunogenic peptides is caused by clonal inactivation. Nature 1986;319:413-415.

7. Ridge JP, Di Rosa F, Matzinger P. A conditioned dendritic cell can be a temporal bridge between a CD4 ${ }^{+} \mathrm{T}$ helper and a T-killer cell. Nature 1998;393:474-478.

8. Ichino M, Mor G, Conover J, Weiss WR, Takeno M, Ishii KJ, Klinman DM. Factors associated with the development of neonatal tolerance after the administration of a plasmid DNA vaccine. J Immunol 1999;162:3814-3818.

9. Sarzotti M, Robbins DS, Hoffman PM. Induction of protective CTL responses in newborn mice by a murine retrovirus. Science 1996;271:1726-1728.

10. Tsukamoto M, Ochiya T, Yoshida S, Sugimura T, Terada M. Gene transfer and expression in progeny after intravenous DNA injection into pregnant mice. Nat Genet 1995;9:243-248.

11. Okuda K, Bukawa H, Hamajima K, Kawamoto S, Sekigawa K, Yamada Y, Tanaka S, Ishii N, Aoki I, Nakamura M, Yamamoto H, Cullen BR, Fukushima J. Induction of potent humoral and cell-mediated immune responses following direct injection of DNA encoding the HIV-1 env and rev gene products. AIDS Res Hum Retroviruses 1995;11:933-943.

12. Toda S, Ishii N, Okada E, Kusakabe KI, Arai H, Hamajima K, Gorai I, Nishioka K, Okuda K. HIV-1specific cell-mediated immune responses induced by DNA vaccination were enhanced by mannan-coated liposomes and inhibited by anti-interferon- $\gamma$ antibody. Immunology 1997;92:111-117.

13. Cease KB. Peptide component vaccine engineering: targeting the AIDS virus. Int Rev Immunol 1990;7:85107. 
14. Ulmer JB, Donnelly JJ, Parker SE, Rhodes GH, Felgner PL, Dwarki VJ, Gromkowski SH, Deck RR, Dewitt CM, Friedman A, Hawe LA, Leander KR, Martinez D, Petty HC, Shiver JW, Montgomery DL, Liu MA. Heterologous protection against influenza by injection of DNA encoding a viral protein. Science 1993;259:1745-1749.

15. Ulmer JB, Deck RR, DeWitt CM, Friedman A, Donnelly JJ, Liu MA. Protective immunity by intramuscular injection of low doses of influenza virus DNA vaccines. Vaccine 1994;12:1541-1544.

16. Ulmer JB, Fu T-M, Deck RR, Friedman A, Guan L, DeWitt C, Liu X, Wang S, Liu MA, Donnelly JJ, Caulfield MJ. Protective CD4 ${ }^{+}$and $\mathrm{CD} 8^{+} \mathrm{T}$ cells against influenza virus induced by vaccination with nucleoprotein DNA. J Virol 1998;72:5648-5653.

17. el-Naggar AK, van Dekken HD, Ensign LG, Pathak S. Interphase cytogenetics in paraffin-embedded sections from renal cortical neoplasms. Correlation with cytogenetic and flow cytometric DNA ploidy analyses. Cancer Genet Cytogenet 1994;73:134-141.

18. Herr W, Linn B, Leister N, Wandel E, Meyer zum Buschenfelde KH, Wolfel T. The use of computerassisted video image analysis for the quantification of $\mathrm{CD} 8^{+} \mathrm{T}$ lymphocytes producing tumor necrosis factor alpha spots in response to peptide antigens. J Immunol Methods 1997;203:141-152.

19. Shirai A, Holmes K, Klinman D. Detection and quantitiation of cells secreting IL-16 under physiologic conditions in BALB/c mice. J Immunol 1993;150:793799.

20. Billingham RE, Brent L, Medawar PB. Activity acquired tolerance of foreign cells. Nature 1953;172:603-605.

21. Mor G, Singla M, Steinberg AD, Hoffman SL, Okuda K, Klinman DM. Do DNA vaccines induce autoimmune disease? Hum Gene Ther 1997;8:293-300.

22. Forsthube T, Yip HC, Lehmann PV. Induction of TH1 and $\mathrm{TH} 2$ immunity in neonatal mice. Science 1996;271:1728-1730.

23. Ridge JP, Fuchs EJ, Matzinger P. Neonatal tolerance revisited: turning on newborn $\mathrm{T}$ cells with dendritic cells. Science 1996;271:1723-1726.

24. Gerdts V, Babiuk LA, van Drunen Littel-van den Hurk S, Griebel PJ. Fetal immunization by a DNA vaccine delivered into the oral cavity. Nat Med 2000;6:929-932. 


\section{PROTOCOL I: PREPARATION OF INFLUENZA VIRUS}

1. Culture MDCK cells (ATCC, No. CCL-34) in a $10 \mathrm{~cm}^{2}$ dish with Minimum Essential Medium (MEM) containing $10 \%$ FCS and antibiotics in a $\mathrm{CO}_{2}$ incubator at $37^{\circ} \mathrm{C}$.

2. Aspirate medium from a confluent cell monolayer.

3. Wash cells once with PBS.

4. Remove PBS and infect cells with $1 \mathrm{ml}$ of FCS-free MEM containing $10^{4} \mathrm{pfu}$ of influenza virus.

5. Place in a $\mathrm{CO}_{2}$ incubator at $37^{\circ} \mathrm{C}$ for $1 \mathrm{hr}$, rocking the dish at $15-30 \mathrm{~min}$ intervals to keep cells moist.

6. After $1 \mathrm{hr}$ of incubation, add $10 \mathrm{ml}$ of MEM medium containing $10 \% \mathrm{BSA}$ and antibiotics, and place in a $\mathrm{CO}_{2}$ incubator at $37^{\circ} \mathrm{C}$ for 3 days.

7. Store supernatant at $-80^{\circ} \mathrm{C}$ until use.

$\underline{\text { Titration of influenza virus }}$

1. Prepare a 6-well tissue culture dish with confluent MDCK cells.

2. Aspirate medium and wash cells once with PBS.

3. Remove PBS and infect cells in duplicate wells with $0.5 \mathrm{ml}$ of the $10^{-5}, 10^{-6}$, and $10^{-7}$ virus dilutions in FCS-free MEM medium.

4. Place in a $\mathrm{CO}_{2}$ incubator at $37^{\circ} \mathrm{C}$ for $1 \mathrm{hr}$, rocking the dish at $15-30$ min intervals to keep cells moist.

5. Before the $1 \mathrm{hr}$ infection is finished, melt $2 \%$ low-melt agarose and place in a $45^{\circ} \mathrm{C}$ water bath to cool. Be sure it cools to $45^{\circ} \mathrm{C}$ before using it to overlay cells. Prepare and warm to $45^{\circ} \mathrm{C}$ MEM medium containing $10 \% \mathrm{BSA}$.

6. Mix equal volumes of $2 \%$ agarose and the MEM medium from step 5.

7. Aspirate the viral inoculum from the cells (from step 4). Overlay each well with $2 \mathrm{ml}$ agarose and allow to solidify at room temperature (RT) or $4^{\circ} \mathrm{C}$. Place in a $\mathrm{CO}_{2}$ incubator at $37^{\circ} \mathrm{C}$ for 3 days.

8. Remove the agarose and add $0.5 \mathrm{ml}$ of $0.1 \%$ crystal violet to each well. Incubate for $5 \mathrm{~min}$ at RT.

9. Aspirate crystal violet and allow wells to dry.

10. Determine the titre by counting plaques within the wells and multiplying by the dilution factor. 


\section{Protocol II: Preparation of Liposome}

Materials:

- L- $\alpha$-phosphatidylethanolamines dioleoyl (DOPE, Avanti Polar-Lipids, Inc.)

- $\quad 3 \beta\left[\mathrm{N}-\left(\mathrm{N}^{\prime} \mathrm{N}^{\prime}\right.\right.$-dimethylaminoethane) carbamoyl] cholesterol (DC-Chol, Avanti Polar Lipids, Inc.)

$\underline{\text { Preparation of } 1 \mathrm{ml} \text { of Liposome }}$

1. Dissolve DC-chol in chloroform at a concentration of $60.1 \mathrm{mg} / 10 \mathrm{ml}$ and store at $-20^{\circ} \mathrm{C}$.

2. Dissolve DOPE in chloroform at a concentration of $59.9 \mathrm{mg} / 10 \mathrm{ml}$ and store at $-20^{\circ} \mathrm{C}$.

3. Mix $100 \mu \mathrm{l}$ each of DC-Chol and the DOPE stock solutions.

4. Evaporate it with evaporator with gentle mixing at $40^{\circ} \mathrm{C}$.

5. Add $1 \mathrm{ml}$ of HEPES buffer (sterile, $\mathrm{pH}$ 7.8) and dissolve the pellet completely with vortex.

6. Hydrate at $4^{\circ} \mathrm{C}$ for 12 to $72 \mathrm{hrs}$.

7. Sonicate it at output $2-3$, duty cycle 30 (twice for $5 \mathrm{~min}$ ).

8. Store at $4^{\circ} \mathrm{C}$ until use.

\section{$\underline{\text { Synthesis of liposome-DNA mixture }}$}

1. Dissolve 5-50 $\mu \mathrm{g}$ of plasmid DNA in $50 \mu \mathrm{l}$ of PBS.

2. Mix $50 \mu \mathrm{l}$ of the DNA solution with $50 \mu \mathrm{l}$ of liposome and pipet several times.

3. Set the liposome-DNA mixture at RT for 15 to $30 \mathrm{~min}$ before administration (Do not incubate the DNA with the liposome for more than $1 \mathrm{hr}$ before administration).

4. Administer $100 \mu \mathrm{l}$ of liposome-DNA mixture per mouse. 


\section{PROTOCOL III: FLUORESCENCE IN SITU HYBRIDIZATION (FISH)}

$\underline{\text { Probe Preparation }}$

Materials:

- Digoxigenin-11-dUTP (1 nmol/ $\mu$ l, Roche Diagnostics Inc., Mannheim, Germany)

- $\quad$ DNA polymerase I (10 U/ $\mu 1$, GibcoBRL)

- 10 x A4 dNTP mix (Roche Diagnostics Inc., Mannheim, Germany)

- $\quad$ DNA polymerase I (0.5 U/ $\mu \mathrm{l}) / \mathrm{DNase} \mathrm{I}(0.4 \mathrm{mU} / \mu \mathrm{l}) \operatorname{mix}(\mathrm{GibcoBRL})$

Probe Labeling

1. Purify PCR product from agarose gel using QIAquick gel extraction kit (Qiagen).

2. Mix following reagents at RT:

a) $10 \times$ A4 dNTP mix, $5 \mu \mathrm{l}$

b) PCR DNA, $1 \mu \mathrm{g}$

c) Dig-11-dUTP, $1 \mu \mathrm{l}$

d) DNA polymerase I, $1 \mu \mathrm{l}$

e) DNA polymerase I/DNase I mix, $4.5 \mu \mathrm{l}$

f) Make up to $50 \mu \mathrm{l}$ with $\mathrm{H}_{2} \mathrm{O}$

3. Incubate the mixture at $15^{\circ} \mathrm{C}$ for $50 \mathrm{~min}$.

4. Stop the reaction at $80^{\circ} \mathrm{C}$ for $10 \mathrm{~min}$.

5. Check the probe on $2 \%$ agarose gel (300-560 bp DNA was visible).

\section{$\underline{\text { Preparation of Specimen Sections }}$}

1. Remove the tissue from the animal.

2. Put the tissue in a disposable vinyl specimen mold.

3. Immediately soak specimen mold into liquid nitrogen.

4. Cut block into $10 \mu \mathrm{m}$ thin sections.

5. Dry slides at RT for $30 \mathrm{~min}$.

6. Wash slides with PBS at RT for 5 min.

7. Incubate slides in $75 \mathrm{mM} \mathrm{KCl}$ at $\mathrm{RT}$ for $10 \mathrm{~min}$.

8. Soak slides in methanol/acetate acid mix (3 vol:1 vol) at RT for $10 \mathrm{~min}$ (to fix tissue).

9. Dry slides at RT for $5 \mathrm{~min}$.

10. Wash slides with PBS at RT for 5 min.

11. Incubate slides with $0.005 \%$ trypsin in $\mathrm{PBS}$ at $37^{\circ} \mathrm{C}$ for $15 \mathrm{~min}$ (remove protein).

12. Wash slides with PBS twice at $4^{\circ} \mathrm{C}$ for $5 \mathrm{~min}$.

13. Incubate slides with $10 \mu \mathrm{g} / \mathrm{ml}$ of RNase in SSC (degrades endogenous RNA).

14. Wash slides with PBS twice at RT for $5 \mathrm{~min}$.

15. Incubate slides in $4 \%$ PFA at RT for 5 min (fix tissue).

16. Wash slides with PBS twice at RT for $5 \mathrm{~min}$.

17. Incubate slides in $0.1 \% \mathrm{NP}-40 / 2 \times \mathrm{SSC}$ at $37^{\circ} \mathrm{C}$ for $30 \mathrm{~min}$.

18. Soak slides in $70 \%, 85 \%$ and $100 \%$ ethanol at RT for 2 min each (to fix tissue).

Detection with FISH method

Materials:

- $\quad$ RNase: Make $1 \mathrm{mg} / \mathrm{ml}$ stock in 2 x SSC. Inactivate DNase by placing in boiling water for 10 min. Freeze in aliquots suitable for $1: 10$ dilution.

- $20 \times \mathrm{SSC}(\mathrm{pH} 7.00): 3 \mathrm{M} \mathrm{NaCl}+0.3 \mathrm{M} \mathrm{Na}$ citrate, $\mathrm{pH}$ 7; filter before use.

- Master mix (50\% formamide, 2 x SSC):

a) Formamide, $5 \mathrm{ml}$

b) $20 \times \mathrm{SSC}, 1 \mathrm{ml}$

Biological Procedures Online • Vol. 3 No. 1 • April 23, $2002 \bullet$ www.biologicalprocedures.com 
c) Dextran sulfate, $1 \mathrm{~g}$

d) Must heat for 1-2 hrs to dissolve. Bring to $\mathrm{pH} 7.0$ with $\mathrm{HCl}$. Bring volume to $7.0 \mathrm{ml}$ with $\mathrm{ddH}_{2} \mathrm{O}$.

- Denaturing solution: $70 \%$ formamide in 2 x SSC (0.7 volume formamide + 0.1 volume 20 x SSC) pH 7.0 with $\mathrm{HCl}$. Bring to volume with $\mathrm{ddH}_{2} \mathrm{O}$.

- Hybridization wash buffer: Prepare 50\% formamide in 2 x SSC (0.5 volume formamide + 0.1 volume 20 x SSC) and adjust $\mathrm{pH}$ to 7.0 with $\mathrm{HCl}$. Bring to volume with $\mathrm{ddH}_{2} \mathrm{O}$.

- 4 x SSC/0.1\% Triton X-100: Dilute $20 \times$ SSC 1:5, adjust pH to 7.0 and then add Triton X-100 to a final concentration of $0.1 \%$. Autoclave.

- Anti-Digoxigenin-Rhodamine polyclonal antibody (Roche Diagnositic Inc., Mannheim, Germany): Dilute to the final concentration with 5\% skim milk in PBS.

$\underline{\text { Day } 1}$

1. Mix:

a) Nick product, $40 \mu \mathrm{l}$

b) $3 \mathrm{M}$ sodium acetate, $4 \mu \mathrm{l}$

c) Salmon sperm DNA $(10 \mathrm{mg} / \mathrm{ml}), 4 \mu \mathrm{l}$

d) $100 \%$ ethanol, $100 \mu \mathrm{l}$

2. Keep at $-80^{\circ} \mathrm{C}$ for $15 \mathrm{~min}$.

3. Centrifuge at $1500 \mathrm{rpm}$ for $30 \mathrm{~min}$ in a microcentrifuge.

4. Dry up.

5. Dissolve DNA in $20 \mu \mathrm{l}$ of a solution containing $70 \%$ master mix and $30 \% \mathrm{ddH}_{2} \mathrm{O}$.

6. Denature probe mixture at $73^{\circ} \mathrm{C}$ for $5 \mathrm{~min}$.

7. Place on ice.

8. Soak treated tissue slides at $73^{\circ} \mathrm{C}$ denaturation solution for $5 \mathrm{~min}$.

9. Incubate tissue slides with $70 \%$ ethanol for 2 min on ice.

10. Incubate tissue slides with $85 \%$ ethanol for 2 min on ice.

11. Incubate tissue slides with $100 \%$ ethanol for $2 \mathrm{~min}$ at RT.

12. Dry tissue slides on $37^{\circ} \mathrm{C}$ hot plate.

13. Incubate with denatured probe mixture.

14. Cover the tissue slides with cover glass and seal with paper cement.

15. Incubate tissue slides at $37^{\circ} \mathrm{C}$ in a moist incubator for 1-3 days.

Day 2

1. Remove paper cement and cover glass.

2. Wash slides three times at $45^{\circ} \mathrm{C}$ with $50 \%$ formamide/ $2 \times \mathrm{SSC}$ for $10 \mathrm{~min}$.

3. Wash slides once at $45^{\circ} \mathrm{C}$ with $2 \times \mathrm{SSC}$ for $10 \mathrm{~min}$.

4. Wash slides once at RT with $2 \times$ SSC for $10 \mathrm{~min}$.

5. Block with $5 \%$ skim milk at RT.

6. Incubate slides with anti-Digoxigenin-Rhodamine $\mathrm{Ab}$ (1:200 dilution, protected from light in all of the following steps).

7. Wash slides with $4 \times \mathrm{SSC}$ at RT for $10 \mathrm{~min}$.

8. Wash slides with $4 \times \mathrm{SSC} / 0.1 \%$ Triton X-100 at RT for $10 \mathrm{~min}$.

9. Wash slides with $4 \times \mathrm{SSC}$ at RT for $10 \mathrm{~min}$.

10. Wash slides with $\mathrm{H}_{2} \mathrm{O}$ at RT for 5 min.

11. Dry slides.

12. Counter stain slides with $0.05 \mu \mathrm{g} / \mathrm{ml}$ of 4,6-diamidino-2-phenylindole in PBS.

13. Store slides at $-4^{\circ} \mathrm{C}$ until counting. 


\section{Protocol IV: Elispot ASSAY}

Materials:

- Blocking solution: RPMI 1640 containing $10 \%$ FCS

- Wash buffer: 1 x PBS containing $0.05 \%$ Tween-20

- Plate: MultiScreen-IP sterile Plate, Millipore (Cat. No. MAIPS4510)

- Anti-mouse IFN- $\gamma$ mAb 1 mg/ml (x 100 in PBS) (PharMingen, Cat. No. 554431)

- Biotinylated anti-mouse IFN-g mAb (x 1000 in PBS) (PharMingen)

- Alkaline phosphatase streptavidin (Vector Laboratories, Inc. CA; Cat. No. SA-5100; working solution: dilute $1 \mu 1$ of alkaline phosphatase streptavidin in $5 \mathrm{ml}$ of PBS containing $0.05 \%$ Tween-20 and 5\% BSA just before use)

- $\quad$ BCIP/NBT phosphatase substrate (Kirkegaard \& Perry Laboratories, Inc., MD; Cat. No. 50-81-18)

1. Incubate $50 \mu \mathrm{l} /$ well of 100 -fold diluted anti-mouse IFN- $\gamma \mathrm{mAb}$ in PBS to ELIspot IP plate at $4^{\circ} \mathrm{C}$ overnight.

2. Discard the $\mathrm{mAb}$ and wash wells once with $200 \mu \mathrm{l} /$ well blocking solution.

3. Incubate $200 \mu \mathrm{l} /$ well blocking solution at RT for $2 \mathrm{hrs}$.

4. Discard the blocking solution.

5. Add $200 \mu \mathrm{l} /$ well of $10^{4}, 10^{5}$ or $10^{6}$ splenocytes with or without antigen $10 \mu \mathrm{g} / \mathrm{ml}$ in RPMI 1640 with $10 \%$ FCS (each sample was stimulated in triplicate with or without antigen at each dose).

6. Place the plate in a $37^{\circ} \mathrm{C}$-incubator at $5 \% \mathrm{CO}_{2}$ for $24 \mathrm{hrs}$.

7. Discard the cell suspension.

8. Wash wells twice with $200 \mu \mathrm{l}$ of $\mathrm{ddH}_{2} \mathrm{O}$ and allow wells to soak for 3-5 min at each wash step.

9. Wash wells three times with $200 \mu 1 /$ well wash buffer.

10. Discard the wash buffer and incubate $100 \mu \mathrm{l} /$ well of 1,000-fold diluted Biotinylated anti-mouse IFN- $\gamma \mathrm{mAb}$ at RT for $2 \mathrm{hrs}$.

11. Wash wells three times with $200 \mu \mathrm{l} /$ well wash buffer.

12. Discard wash buffer and incubate with $50 \mu \mathrm{l} /$ well of diluted alkaline phosphatase streptavidin at RT for 1-2 hrs.

13. Wash the plate six times with $200 \mu \mathrm{l}$ of $\mathrm{ddH}_{2} \mathrm{O}$ containing $0.05 \%$ Tween-20.

14. Incubate the plate with $50 \mu \mathrm{l} / \mathrm{well}$ of BCIP/NBT phosphatase substrate at RT for $20 \mathrm{~min}-1 \mathrm{hr}$.

15. Wash the plate three times with $200 \mu \mathrm{l}$ of $\mathrm{ddH}_{2} \mathrm{O}$.

16. Dry the plate and count spots with a computer-assisted video image analysis (CVIA) system. 